\title{
A STUDY OF THE GATHERING STYLES OF INDONESIAN CULTURE
}

\author{
インドネシア文化に扔ける集まりの様式に関する研究 \\ Muhammad Yusri Lukman*, Takeshi SUZUKI**, Michihiro KITA***, \\ Yuko YOSHIZUMI**** and Shigeki MATSUBARA***** \\ ムハンマド ユスリ ルクマン, 鈴木 毅, 木多道宏, \\ 吉住 優子, 松原茂 樹
}

This paper aims to analyze gathering styles characteristic of Indonesian culture. From fieldwork and the completed questionnaires of 30 Indonesian students and their families living in Japan, we found the following;

1) The families of Indonesian students often invite 10 to 20 guests to their Japanese houses or apartments and more than 50 to their homes in Indonesia.

2) Many Indonesian families have and use western style furniture. But when gathering in a home, they sit in a circle on mats (tikar) on the floor with males and females sitting apart from each other. This style is both in Japan and in Indonesia.

3) When they gather at a public hall for Islamic lectures, they sit on the floor in a circle, and males and females are separated.

Gathering practices embedded in Indonesianculture are maintained in a Japanese environment.

Keywords: Gathering, Tudang Sipulung, Tikar, Sitting on the Floor, Indonesia

集まり，ツダンシプロン，敷物，床座，インドネシア

\section{Introduction}

Gathering are an important aspect of Indonesian culture. In earlier times, in addition to living in groups, traditional Indonesian tribes often held events or conducted rituals that involved a gathering. Even now, the gathering culture is well preserved. At this time, human interactions are more varied, depending on the needs of the people involved.

This gathering is a forum for social interactions, not only for family members, but also for friends, neighbors, or members of other communities. This activity can be organized by anyone, including families, friends, social communities, and groups. Many places such as houses, community halls, schools, offices, restaurants, and open spaces, and others can be used for gatherings. The types of activities conducted are also varied, and include family gatherings, Islamic lectures, celebrations, wedding parties, and reunions. The practice of gathering has become part of the culture and lifestyle of Indonesian community, from the children to the elderly, both males and females. A gathering can be held at any time of the day (morning, noon, afternoon, or night).

The purpose of this research is to study the gathering activities that are carried out inside and outside the house, as part of the social interactions characteristic of Indonesia culture, and to learn about the gatherings that are held by members of Indonesian community living in Japan.

\section{Gathering / Tudang Sipulung}

For many years, democratic values have been adopted in the community of Bugis-Makassar. Cultural practices in Bugis-Makassar since antiquity are known as Tudang Sipulung. The words Tudang Sipulungi) literally means sitting together. However, in practice, this is a place for people to voice their interests, in order to find solutions to the problems they face. Tudang sipulung can be also interpreted as a forum that mediate between the interests of the community and the government.

Communities in Makassar often carry out informal activities
* Grad. Student, Dept. of Global Architecture, Graduate School of Engineering. Osaka University

** Prof., Faculty of Architecture, Kinki University, Dr. Eng.

*** Prof., Dept. of Global Architecture, Graduate School of Engineering, Osaka University, Dr. Eng.

**** Researcher, Dr. Eng.

***** Associate Prof., Dept. of Global Architecture, Graduate School of Engineering, Osaka University, Dr. Eng

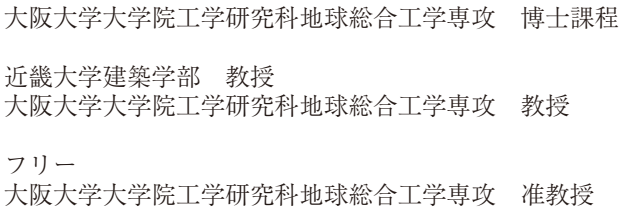

大阪大学大学院工学研究科地球総合工学専攻 博士課程

近畿大学建築学部 教授

大阪大学大学院工学研究科地球総合工学専攻 教授

フリー

大阪大学大学院工学研究科地球総合工学専攻 准教授 


\section{INFORMAL TUDANG SIPULUNG}

Location : Barrang Lompo Island, Makassar

D a t e : June, 2013

- This activity was held outside the house, in the yard.

- They are sitting on the bale-bale (seat made from bamboo) and discussing their daily lives. their houses were close to each other (neighbors).

- This activity was held without an announcement (it was not planned) and lasted for two hours (morning).
- All the participants were male and
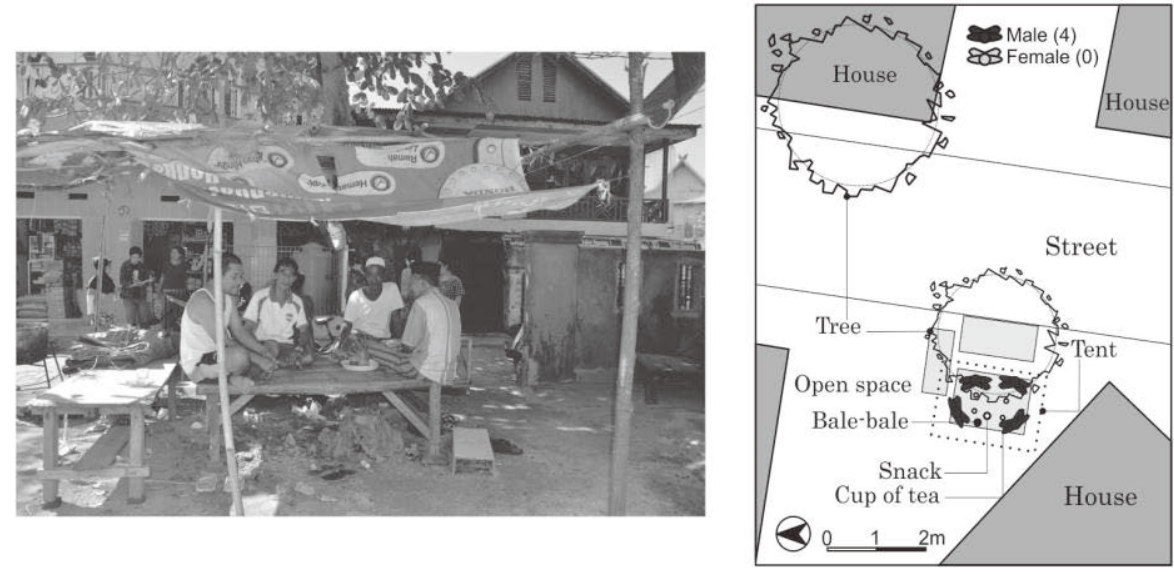

\section{SEMIFORMAL TUDANG SIPULUNG}

Location : Indonesia Moslem University, Makassar

D a t e : December, 2012

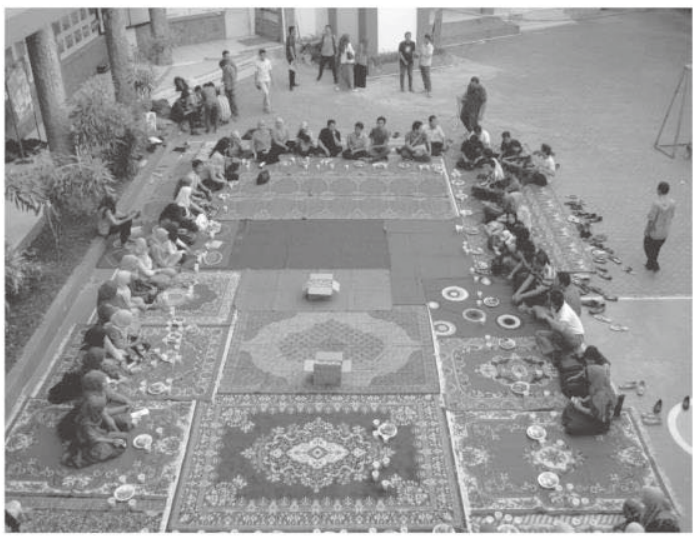

- This activity was held on campus in the yard.

- They are sitting on tikar (mats) on the floor and discussing solution for improving public health services.

- The participants are students and lecturers of the medical faculty.

- The committee makes a general announcement about this activity which lasts for three hours (afternoon).

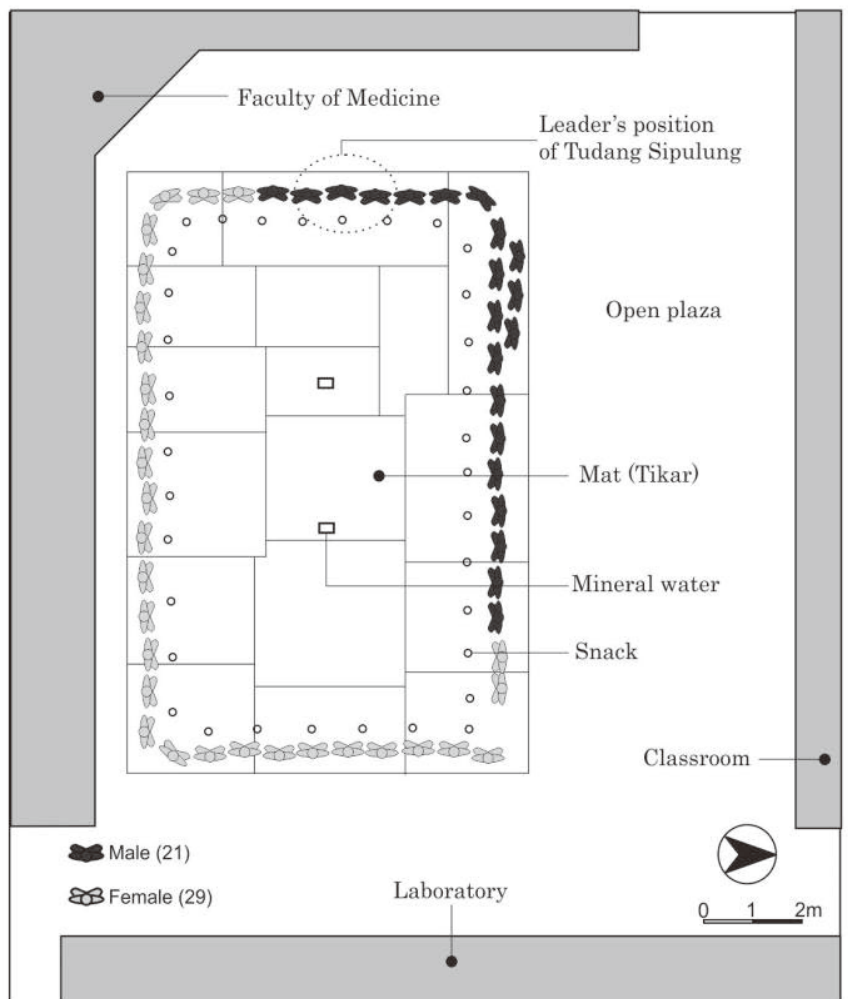

Fig. 1 Informal and Semiformal Tudang Sipulung

during tudang sipulung. For example, they discuss and find solution to a problems. The places used are not only indoors but also outdoors. Some places are used often, such as living rooms, meeting rooms, class rooms, cafes, barugasii), terraces, yards, parks, and bale-bale ${ }^{i i i)}$. This activity can be conducted in the mornings, afternoons, or evenings. Usually a meeting lasts between two and four hours.

There is no official announcement before the activity is held. Usually, however, some direct information or unofficial information is conveyed, such as by word of mouth, phone, or short messages. The place is also usually determined by mutual agreement, or determined at the moment the event commences. The number of participants is limited, so that communication can be more effective.

One example of informal tudang sipulung is on Barrang Lompo Island. The local community here often has small meetings. People gather without an appointment. Usually they talk about many things, such as their jobs, the neighborhood environment, their social lives, politics, and other topics.

Generally, all participants can express their opinions in informal tudang sipulung. They are required to express their opinions even when they are the same as those of other participants, or have already been raised by previous participants. If any of the participants do not agree, then they should express that opinion openly in that tudang sipulung, and 
give the reason that they do not agree. These reasons should be disclosed rationally. Decisions reached in tudang sipulung are based on a common will and common interest.

Another example is that semiformal tudang sipulung that held by the Faculty of Medicine, at the Indonesian Muslim University. Here these activities were held outdoors in order to create a relaxed atmosphere that is expected to strengthen the familiarity of each participant. The committee delivered information for this activity through announcements. It was held in the afternoon, and lasted about two hours. Participants are students and lecturers (Fig. 1).

\section{Previous Study}

Some researches such as Yamamoto (1997) have considered the basic formation of a city, and considered the cultural values (adat) that serve as guidelines for the way of life in the local communities ${ }^{1)}$. Sawada (1998) considered dwellings in terms of the behavioral environment, and focused on the seating style and places for certain behaviors in dwelling units ${ }^{2}$. Bin Li (1999) conducted research on the change of sitting styles, from sitting on the floor to sitting on chairs in China, and based it on four stages: age, appearance, expansion, and generalization of sitting on chair ${ }^{3)}$.

Another research study by Wiyancoko (1999) considered the visual characteristics of a seat in Indonesia's Javanese community, and its relationship with the social values that are relevant in Javanese culture ${ }^{4}$. Finally, there was a study by Yamamoto (2012) about activities performed by the community on bale-bale as a common space. This activity involves not only family members, but also neighbors, and is performed outside of the house ${ }^{5)}$

\section{Field Survey and Method}

a) Questionnaire method were conducted of the Indonesian community living in Japan. Thirty respondents were used in this research. They include students who are studying at Osaka University and some workers from Osaka. The questions were specific to gathering activities that were

Table 1 Data of Respondents

\begin{tabular}{|l|r|c|}
\hline \multicolumn{1}{|c|}{ Gender } & Number & (\%) \\
\hline Male & 22 & 73.33 \\
\hline Female & 8 & 26.67 \\
\hline Total & $\mathbf{3 0}$ & $\mathbf{1 0 0 . 0 0}$ \\
\hline \multicolumn{1}{|c|}{ Hometown } & Number & $(\%)$ \\
\hline Central Java & 4 & 13.33 \\
\hline West Java & 6 & 20.00 \\
\hline East Java & 3 & 10.00 \\
\hline Jakarta & 8 & 26.67 \\
\hline Bali & 1 & 3.33 \\
\hline South Sulawesi & 2 & 6.67 \\
\hline West Sumatera & 2 & 6.67 \\
\hline Lampung & 2 & 6.67 \\
\hline Yogyakarta & 2 & 6.67 \\
\hline Total & $\mathbf{3 0}$ & $\mathbf{1 0 0 . 0 0}$ \\
\hline
\end{tabular}

conducted at home. The data are presented in graphic form. This method is used to compile information about the ways and customs of gatherings in their own houses (Table 1).

b) Case studies and field surveys were conducted at three houses / an apartment house in Japan, and two houses in Indonesia. Some of the data collected in this survey included photos of the rooms, and especially the rooms always used for gatherings, documentation photos of gatherings at their homes, and the furniture. Interviews were conducted with the families to learn what processes are followed for gatherings in thier homes. All of these houses will be redrawn, to depict the existing conditions, and the room's setting when the gatherings were held. The subsequent analysis was based on the results of the direct surveys of the houses.

c) Gatherings at community halls in Japan were also considered. The place name for this gathering is the International House at Osaka University. This place is one of the buildings always used by the Indonesian community for its gatherings. This field survey was carried out on the Islamic lecture activities organized by Osaka Muslim community. Some of the data collected at this gathering are photos of the rooms which were used, the number of participants by gender, maps of sitting positions, and supporting facilities. In addition, in-depth interviews were also conducted with some of the participants who attended, and the organizers of this gathering.

\section{Results}

\subsection{Gathering at Houses in Japan}

a. Participants

Number of participants

\begin{tabular}{|c|c|c|c|c|c|c|}
\hline \\
\hline & $\square 3-5$ & $\square 6-10$ & 웡 $11-15$ & 图 $16-20$ & 国 $21-30$ & \\
\hline 5 & & 11 & & 8 & 8 & 2 \\
\hline $14.7 \%$ & & $32.4 \%$ & & $3.5 \%$ & $23.5 \%$ & 5.9 \\
\hline
\end{tabular}

Fig. 2 Ratio of Gathering Participants in Japan

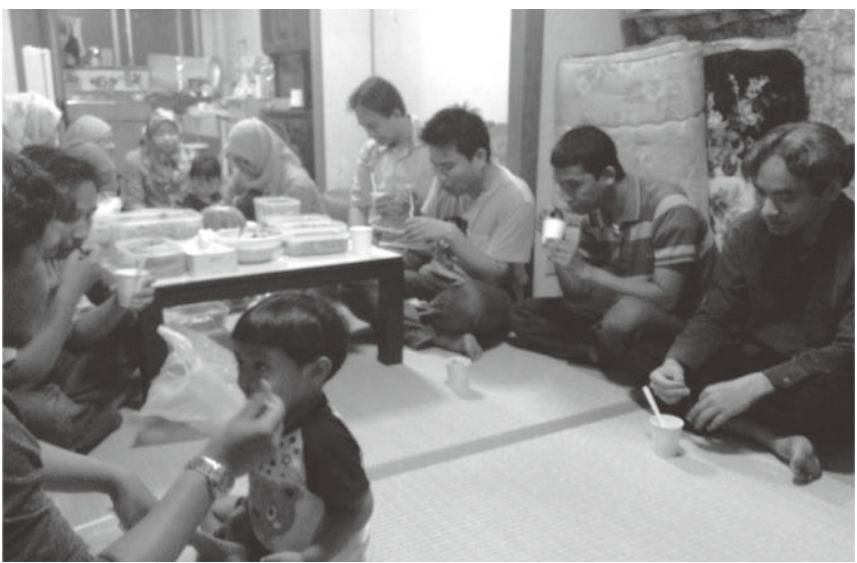

Photo 1 Gathering at a House in Japan 
The number of participants present in gatherings was quite varied, and included men and women. The number of gatherings that were attended by more than 6 participants was 29 cases $(85.3 \%)$, and the number attended by more than 11 participants was 18 cases $(52.9 \%)$. Participants were friends or members of Indonesian community. Sometimes they also invited foreigners they knew who had a close relationship with Indonesian community to attend (Fig. 2, Photo 1).

\section{b. Program}

Some activities carried out by Indonesian community in Japan included farewell parties, breaking fasts together, chatting, Islamic lectures, sharing lunches or dinners, celebrations, reunions, and New Year's parties (Table 2). Invitations are usually delivered directly (Fig. 3). These gatherings laste from two to three hours. The host typically prepares some food for these gatherings.

Table 2 Name of Gathering (House in Japan)

\begin{tabular}{|l|c|c|c|}
\hline \multicolumn{1}{|c|}{ Name of Gathering } & Total & $\begin{array}{c}\text { Average of } \\
\text { Participants }\end{array}$ & Food \\
\hline Farewell party & 3 & 10 & $\mathrm{O}$ \\
\hline Breaking fast together & 5 & 20 & $\mathrm{O}$ \\
\hline Chatting & 8 & 12 & $\mathrm{O}$ \\
\hline Islamic lecture & 8 & 25 & $\mathrm{O}$ \\
\hline Lunch together & 1 & 8 & $\mathrm{O}$ \\
\hline Dinner Together & 1 & 8 & $\mathrm{O}$ \\
\hline Celebration & 6 & 17 & $\mathrm{O}$ \\
\hline Reunion & 1 & 10 & $\mathrm{O}$ \\
\hline New Year's party & 1 & 15 & $\mathrm{O}$ \\
\hline
\end{tabular}

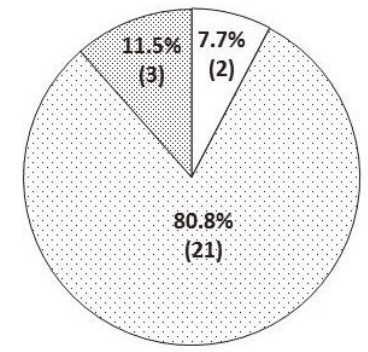

$\square$ Invitation letter

$\exists$ Direct information

圆Announcement

$$
\mathrm{N}=30
$$

Number of participants

Fig. 3 How Participants were Invited to a House Gathering in Japan

\section{c. Setting}

The rooms used to hold gatherings in Japan are always the living rooms (ruang tamu)v), family rooms (ruang keluarga)vi), and bedrooms (Fig. 4). Guests sit on tatami or tikar (mats)iv) on the floor, take off their shoes, forming a circle around the room and facing each other. Most members of Indonesian community who live in Japan have small and/or medium size tikar (mats) at their houses/apartments (70\%), which can be used at any time (Fig. 5). They get these tikar (mats) from their friends, who have moved away or even gone back to Indonesia, or buy them at home center. Men and women sit apart from each other, and men sit closer to the entrance so as to keep female group privacy.

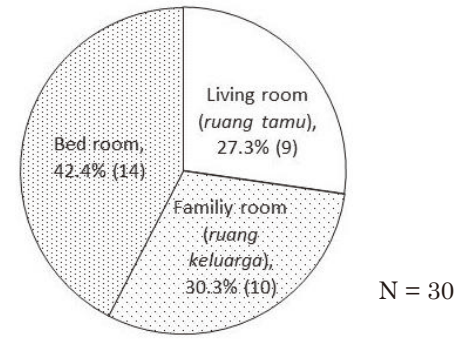

Fig. 4 Ratio of Rooms Used For Gatherings in Japan

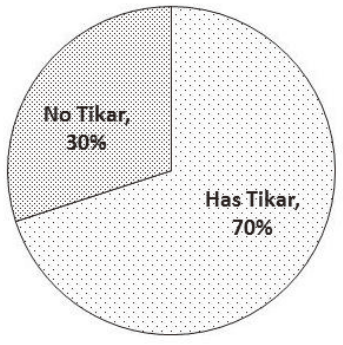

Fig. 5 Ratio of Houses in Japan that have Tikar (Mats)

\section{d. Case Study of Gatherings in Japanese Houses}

Three houses in Japan serve as case studies for this research. Two houses were occupied by Indonesian students who were studying in Japan, and their families, and one house belonged to family of Japanese and Indonesian spouse. These three houses are located in three different city, Ibaraki, Toyonaka, and Minoo of Osaka.

The hosts usually invite their friends to a gathering at their home directly. Gatherings are for farewell parties, breaking fasts together, and Islamic lectures. These gatherings were attended by about 18 to 20 people, were held over the afternoon and evening, and lasted two to three hours.

For these gatherings, they used one or two rooms, depending on the number of participants. The rooms used were living rooms, family rooms, or bedrooms. Guests sit on tikar on the floor. The tikar belong to the hosts, and each family has two or three tikar in their home. Men and women sit apart from each other. Sometimes they have to move some furniture to get enough space for people to sit. During these gatherings, they also provided food prepared by the host, but sometimes they also cooked together before the gathering began (Fig.7).

\subsection{Gathering at Houses in Indonesia}

\section{a. Participants}

The number of participants was usually attended to gathering between 10 to more than 100 persons, and consisted of men and women. Participants included relatives, friends, and neighbors (Fig. 6).

Number of participants

\begin{tabular}{|c|c|c|c|c|}
\hline$\square 10-20$ & $\square 21-40$ & $61-100$ & 閣 101 & -500 \\
\hline 14 & 19 & 13 & 9 & 8 \\
\hline $22.2 \%$ & $30.2 \%$ & $20.6 \%$ & $14.3 \%$ & $12.7 \%$ \\
\hline
\end{tabular}

Fig. 6 Ratio of Gathering Participants in Indonesia

\section{b. Program}

Some of the activities held in Indonesia gatherings included breaking fasts together, chatting, Islamic lectures, celebrations, reunions, youth meetings, and neighbor meetings. Invitations to attended were usually sent by letter, or they were made directly, 


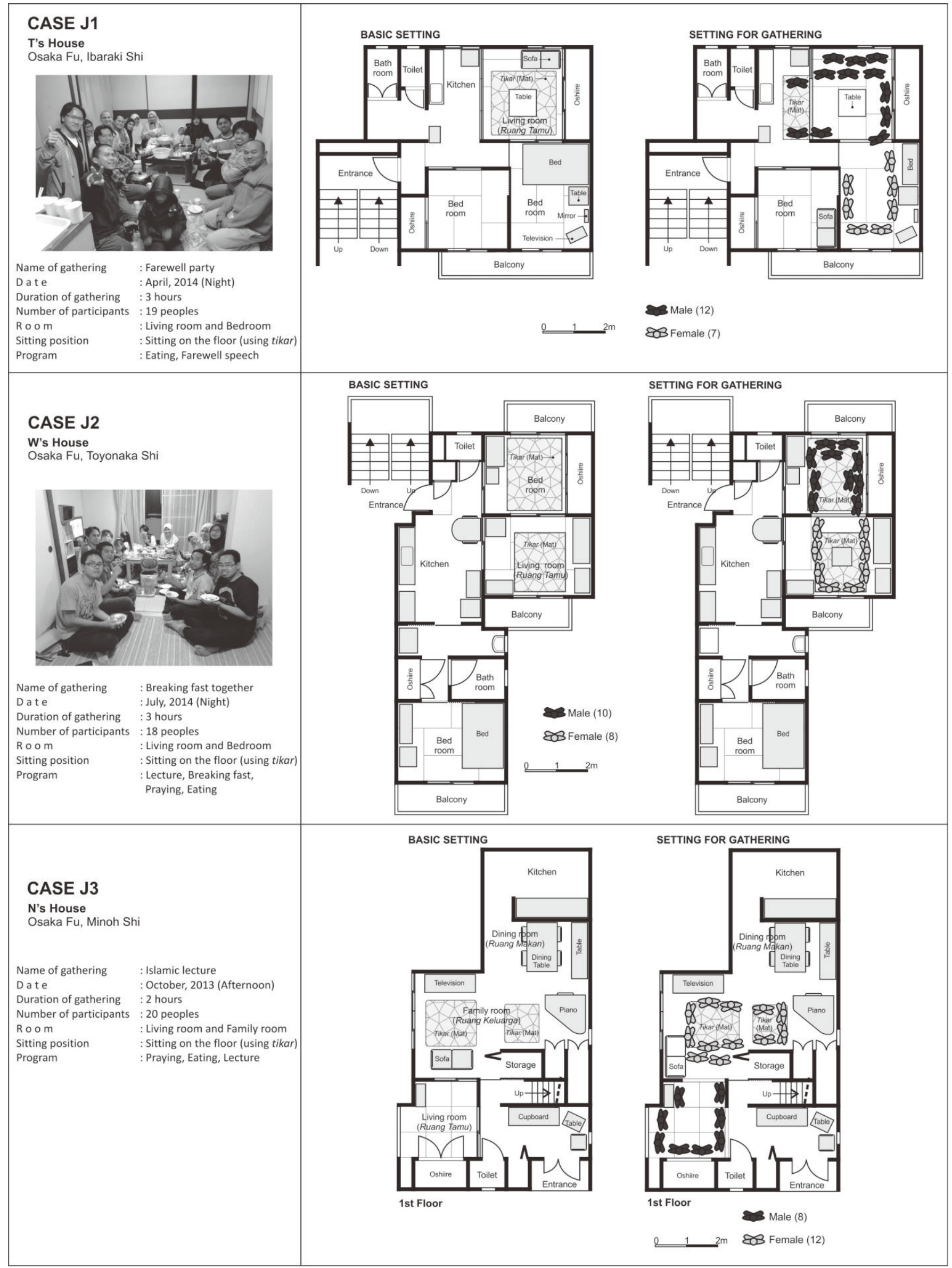

Fig. 7 Gathering at Houses in Japan 
or using announcements through the loudspeaker at the mosque. These gatherings lasted two to three hours. Typically, the host prepared some food for these gatherings (Table 3, Fig. 8).

Table 3 Name of Gathering (House in Indonesia)

\begin{tabular}{|l|c|c|c|}
\hline \multicolumn{1}{|c|}{ Name of Gathering } & Total & $\begin{array}{c}\text { Average of } \\
\text { Participants }\end{array}$ & Food \\
\hline Breaking fast together & 2 & 70 & $\mathrm{O}$ \\
\hline Chatting & 15 & 25 & $\mathrm{O}$ \\
\hline Islamic lecture & 14 & 80 & $\mathrm{O}$ \\
\hline Celebration & 26 & 150 & $\mathrm{O}$ \\
\hline Reunion & 2 & 18 & $\mathrm{O}$ \\
\hline Youth meeting & 1 & 35 & $\mathrm{O}$ \\
\hline Neighbor meeting & 3 & 25 & $\mathrm{O}$ \\
\hline
\end{tabular}

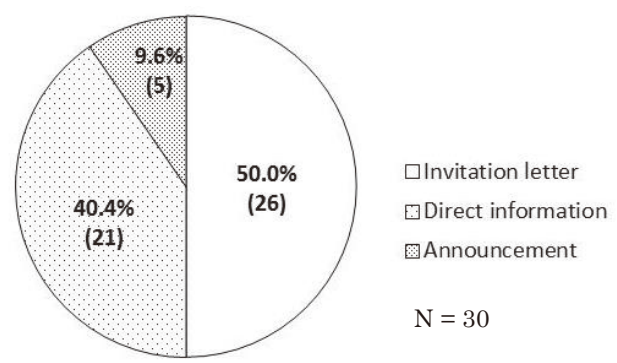

Fig. 8 How Participants were Invited to a House Gathering in Indonesia

\section{c. Setting}

Gatherings were held in a home, using living rooms (ruang tamu)v), family rooms (ruang keluarga)vi), dining rooms, yards, terraces, garages, and streets infront of the house. They usually sit on tikar (mats) on the floor, on chairs, or a combination of both. They usually sit around the room, take off their shoes, and sit in a circle on tikar on the floor. Normally, men are sitting near the main entrance of the house. The people who sit outside the house would adapt to the space provided. Generally, houses in Indonesia have tikar of medium or large size, and every house has three to five tikar. They buy these tikar at traditional markets or supermarket. Homeowners also usually have to move some furniture to create a large enough space, if quite a lot people attend. (Fig. 9-10, Photo 2)

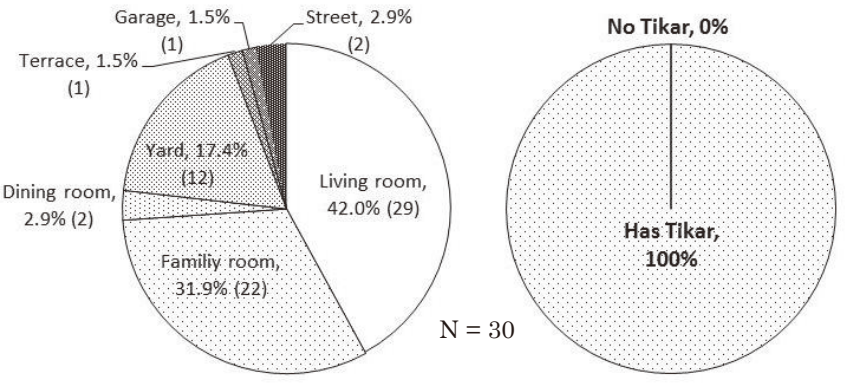

Fig. 9 Ratio of The Rooms For Gathering in Indonesia
Fig. 10 Ratio of House in Indonesia That Has Tikar (Mat)

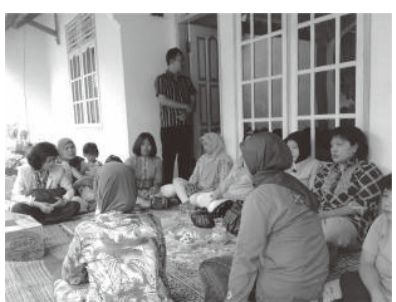

Using tikar (mat)

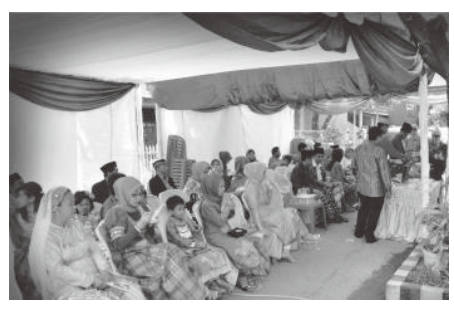

Using chair
Photo 2 Gathering at House in Indonesia

\section{d. Case Study of Gatherings in an Indonesian House}

Gatherings at home, is one of the activities practiced by Indonesian community. This case is based on two houses in Makassar (South Sulawesi), Indonesia. The gatherings conducted are wedding parties held on the morning, and Islamic lectures held on the afternoon.

The hosts invite their relatives, friends, and neighbors by letter and/or by direct information to a gathering at their home. These gatherings were attended by around 40 to 80 people, and lasted for two to three hours. The rooms used were always located at the front of the house, so they were easily accessible to the participants. These rooms are the living rooms and family rooms, and some even used dining rooms and terraces, because of the many participants who attended. So, the room used depends on its capacity and the number of participants.

Men and women sit apart from each other. They sit on tikar and chairs around the room, facing each other. Usually some of the furniture has to be moved to another room to get enough space for people to sit. The hosts own the tikar used seating. They have five tikar of a medium and/or large size. During this gathering, food that has been prepared by the host or a catering service is also provided. (Fig. 11)

\subsection{Comparing Gatherings in Japan and Indonesia}

There are some differences between gatherings in Japan and Indonesia. These differences include, among others, that 1) the number of participants in Japan were fewer (3 to 30 people) than in Indonesia (10 to 500 people); and 2) every house in Indonesia had a gathering, while $23 \%$ of houses in Japan never held a gathering (Fig. 12).

The most frequent reason for gathering in Japan and Indonesia were celebrations ( $57.9 \%$ and $66.7 \%$ ), and then Islamic lectures $(42.1 \%$ and $33.3 \%)$. Sitting positions for gatherings in Japan all used tikar and tatami, while those in Indonesia sometimes also used chairs or a combination of both (Fig. 13-14, Table 4).

Though the number of participants is slightly small and seating style is a little different, Indonesian families invite many guests to Japanese houses. For Indonesian people, houses are not only places for family. Homeowners receive guests at any time. In addition, they will also sometimes hold gatherings and invite 
CASE I1

H's House

Makassar, South Sulawes

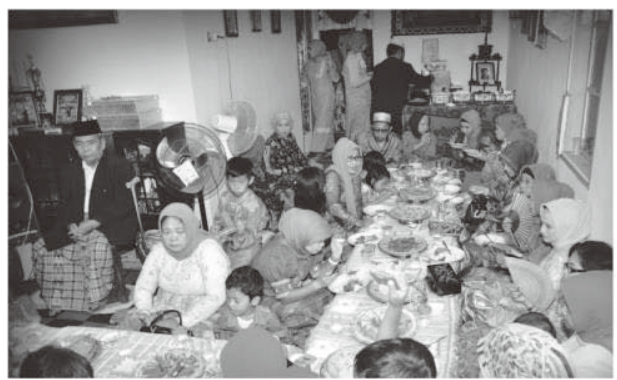

Name of gathering

Date

Wedding party

: Maret, 2013 (Morning)

Duration of gathering

Number of participants :

Room

45 peoples

Sitting position

: Living room, Family room, Dining room, and Terrace

Sitting on the floor (using tikar) and chairs

Program
BASIC SETTING

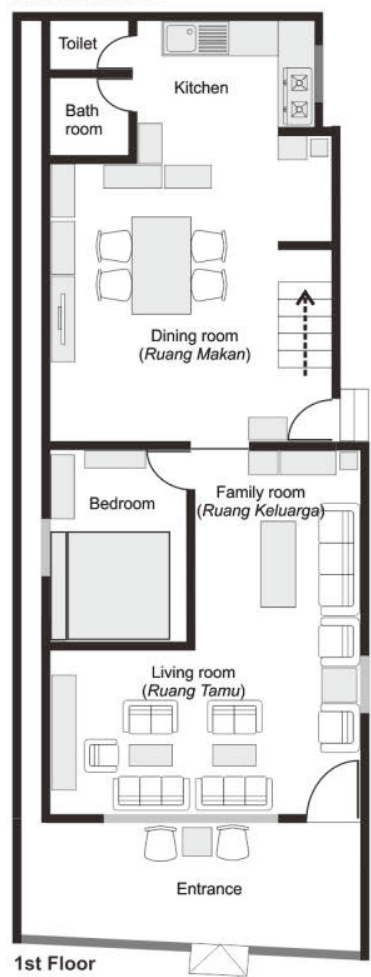

SETTING FOR GATHERING

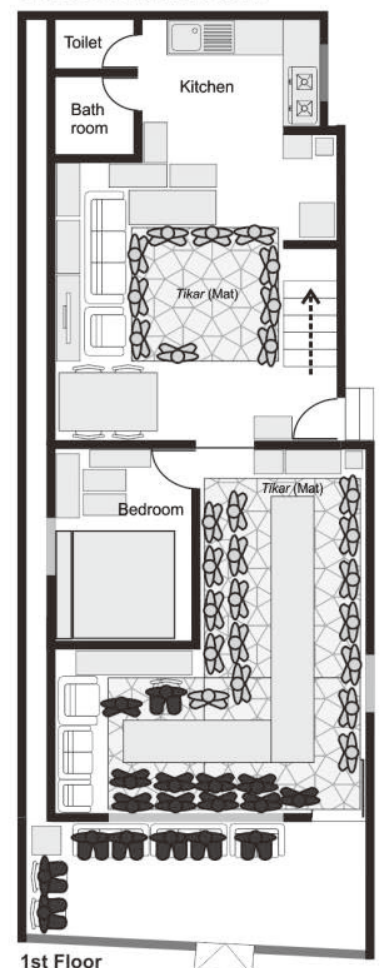

\section{CASE 12}

B's House

Makassar, South Sulawes

$\begin{array}{ll}\text { Name of gathering } & : \text { Islamic lecture } \\ \text { Da t e } & \text { : February, 2013 (Afternoon) } \\ \text { Duration of gathering } & : \text { 2 hours } \\ \text { Number of participants } & : 58 \text { peoples } \\ \text { R o o m } & : \text { Living room, Family room and Terrace } \\ \text { Sitting position } & : \text { Sitting on floor (using tikar) } \\ \text { Program } & : \text { Pray, Lecture, Eating }\end{array}$

Pray, Lecture, Eating

BASIC SETTING

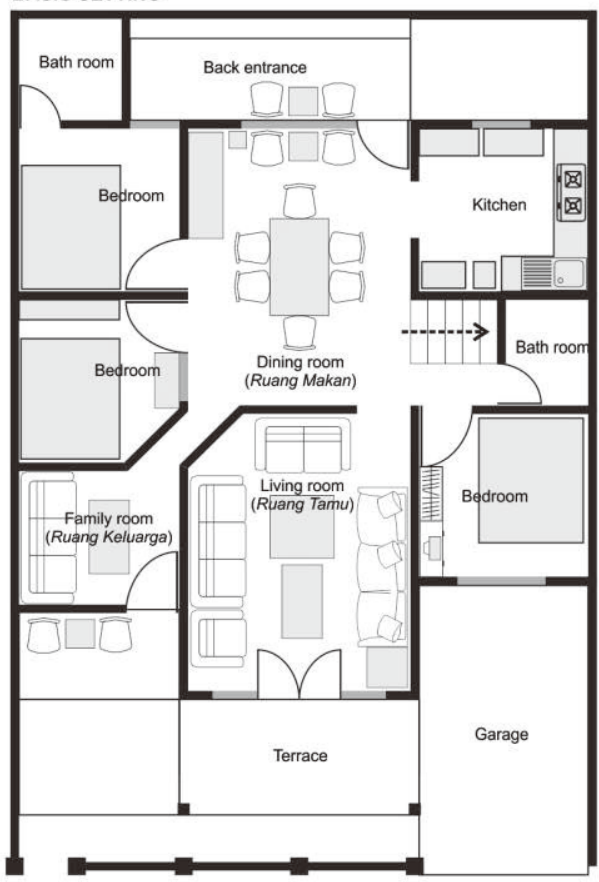

1st Floor
SETTING FOR GATHERING

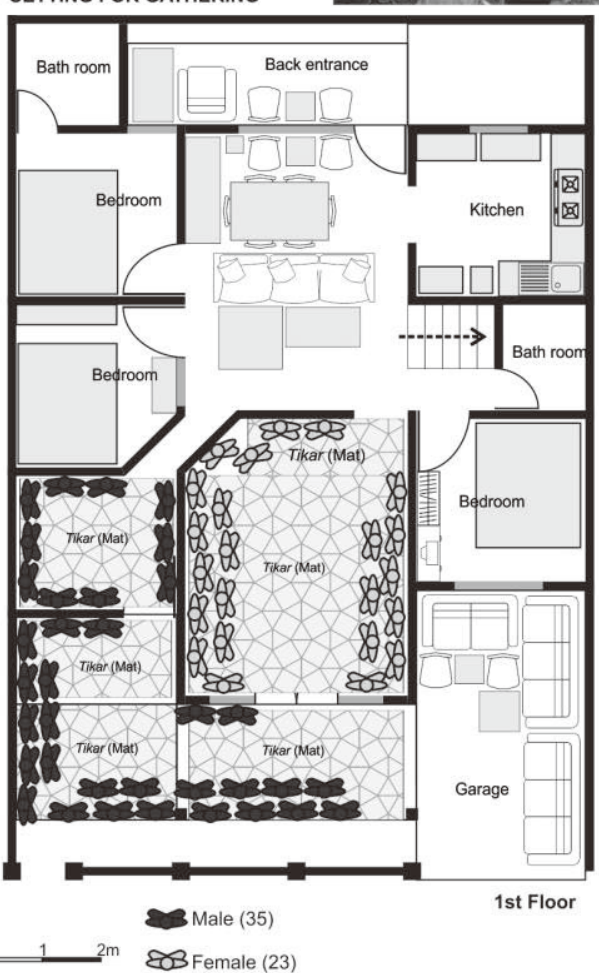

Fig. 11 Gathering at Houses in Indonesia 
people in rather large numbers. Islamic lectures and celebration are some of the gatherings often conducted.

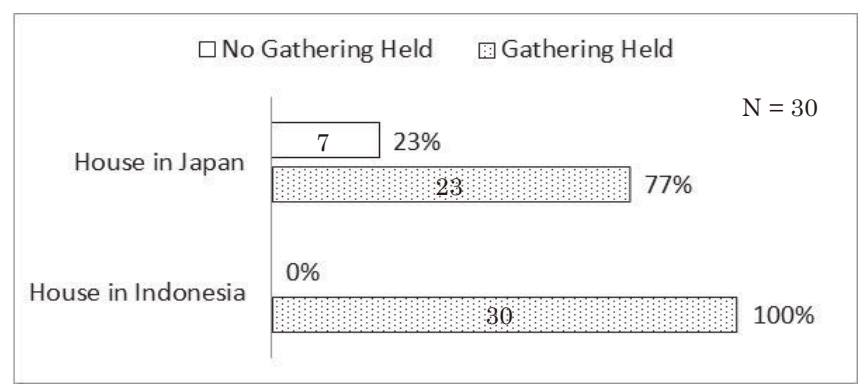

Fig. 12 Ratio and Number of Houses that did and did not Hold Gatherings

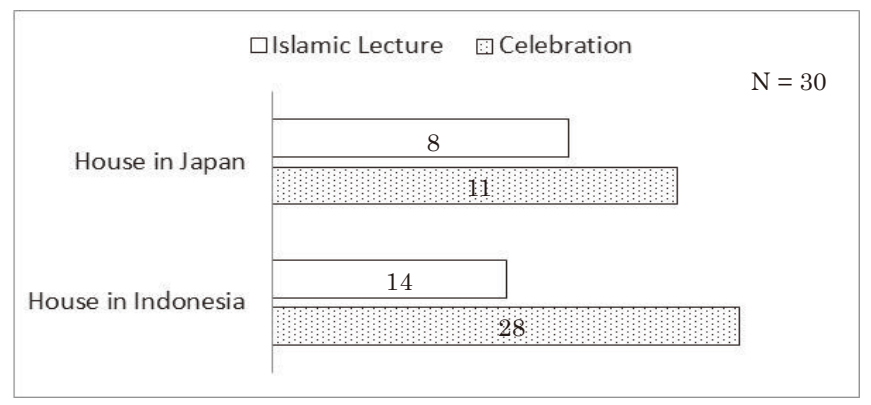

Fig. 13 Types of Gatherings in the House

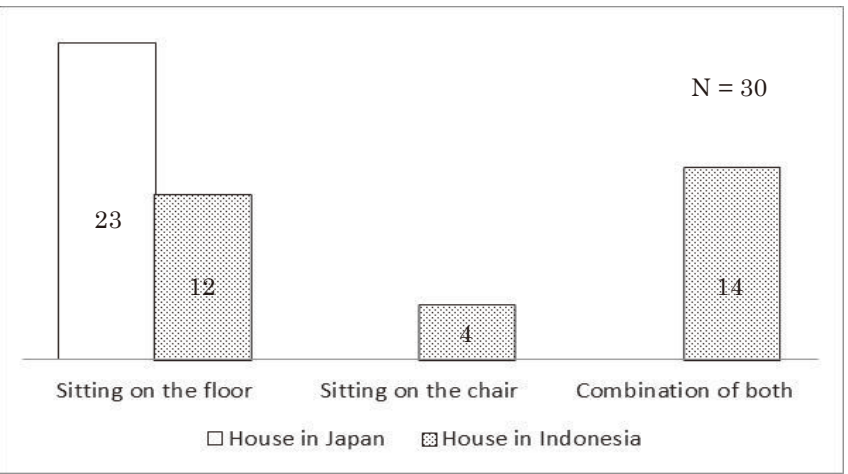

Fig. 14 Sitting Position at Gatherings

Table 4 Comparing of Gathering in Japan and Indonesia

\begin{tabular}{|l|l|l|}
\hline \multirow{2}{*}{ Item } & \multicolumn{2}{|c|}{ Gathering Style of Indonesian Culture } \\
\cline { 2 - 3 } How invited (in general) & House in Japan & \multicolumn{1}{c|}{ House in Indonesia } \\
\hline \hline Dumber of participants & $3-30$ & $\begin{array}{l}\text { Invitation letter, } \\
\text { Direct information, } \\
\text { Announcement }\end{array}$ \\
\hline Room used & $\begin{array}{l}\text { Living room, } \\
\text { Family room, } \\
\text { Bedroom }\end{array}$ & $\begin{array}{l}\text { Living room, Family room, } \\
\text { Dining room, Terrace, } \\
\text { Yard, Garage, Street }\end{array}$ \\
\hline Seating & $\begin{array}{l}\text { Sitting on the floor } \\
\text { (tatami or tikar })\end{array}$ & $\begin{array}{l}\text { Sitting on the tikar, } \\
\text { Sitting on the chair, } \\
\text { Combination of both }\end{array}$ \\
\hline
\end{tabular}

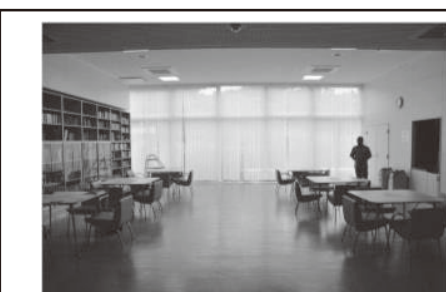

Normal lobby setting Basic Setting

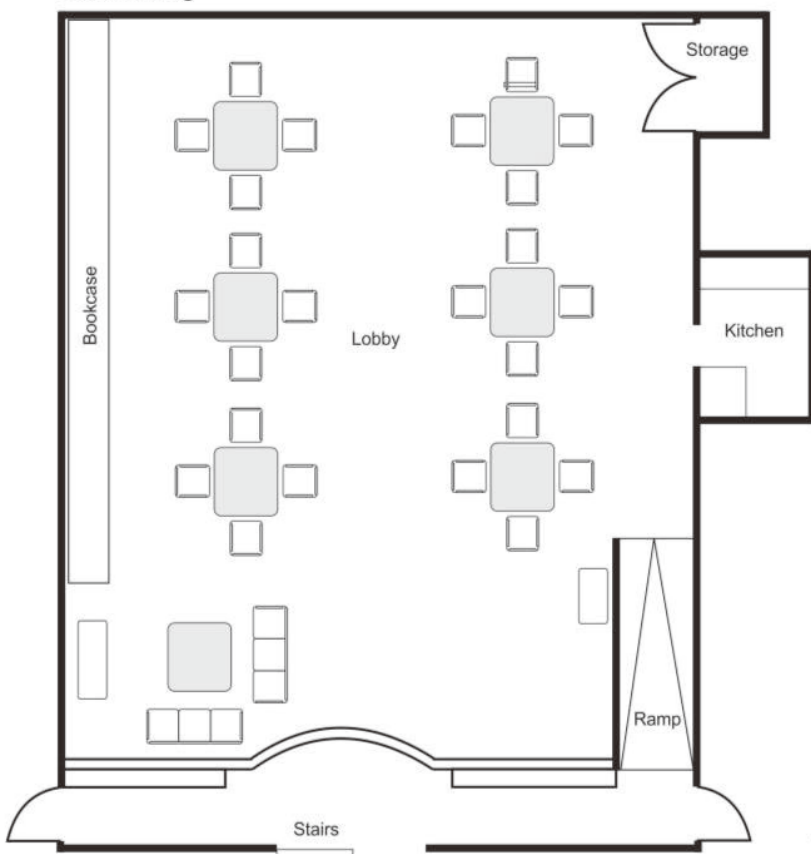

Male (26)

\&8 Female (12)

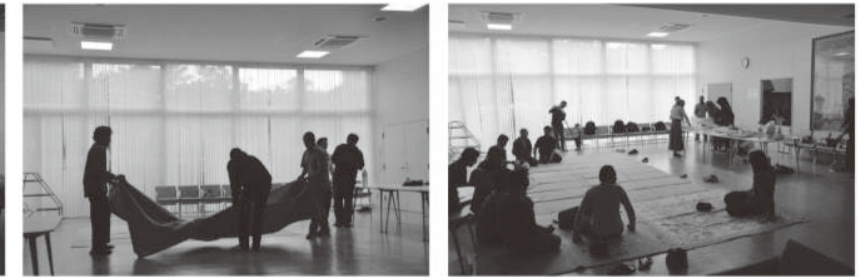

Preparing for the Islamic lecture

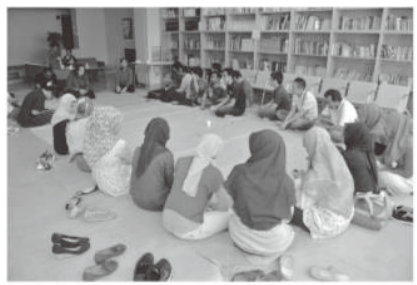

Islamic lecture

Setting For Islamic Lecture (June, 2014)

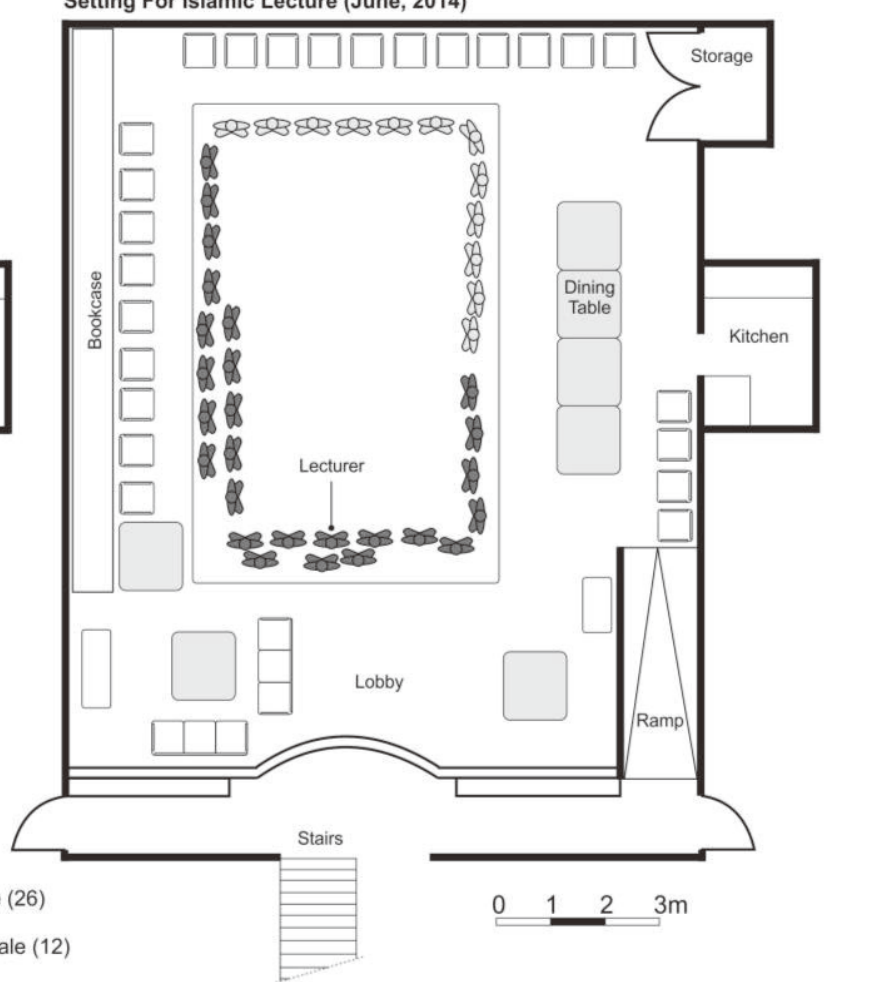

Fig. 15 Osaka University International House Lobby 


\subsection{Gathering at Community Hall}

To hold several gatherings, the Indonesian people who live in Japan, and especially in Osaka, usually use a community hall. This building is chosen because it can accommodate more people, and is close to where the Indonesian community lives.

The International House of Osaka University is located on Toyonaka campus. International students who live or study in Osaka University commonly use the lobby of the International House for activities by international students who live or study in Osaka University. The lobby is open from morning until night. Normally, this place is used for studying or small group discussions. It is also used for many other activities, such as parties, meetings, and bazaars. In the lobby there are bookcases, televisions, sofas, tables, chairs, kitchen and storage facilities, and toilets.

Indonesian Muslim communities have always used the lobby of International House as a place for Islamic lectures. This activity is held once a month, and it is held once every two months in the International House lobby. About 50 peoples attend these lectures. These people are not only students, but also workers and their families. The Islamic lectures last about four hours. To use this lobby, organizers must get permission from Osaka University International House Management a week before the lecture. Arranging the room for an Islamic lecture requires some changes, since the lecture does not require tables and chairs, so chairs are replaced with tikar (mats) as seats. The participants have to take off their shoes before step on the tikar. In addition, some people are responsible for bringing the food that will be served during the lecture. (Fig. 15)

\section{Conclusion}

Indonesian culture includes the practice tudang sipulung (sitting together). When people encounter problems among family members, neighborhood, or others, they sit on the floor and have a discussion. From the fieldwork and questionnaires, completed by 30 Indonesian students and their families living in Japan, we found the following:

a. Indonesian students' families invited many people to their houses. In Japan, they often invite more than 3 to 30 people to their Japanese houses or apartments, while in Indonesia they often invite more than 10 to more than 100 people.

b. Many Indonesian families have and use western style furniture, but when gathering at home, they usually take off their shoes, and sit on the floor in a circle, with males and females sitting separately. They always use tikar (mats) as cushions. This style is common to both Japanese and Indonesian houses.

c. This style of sitting on the floor using tikar is the same as that used when the Indonesian Muslim community has Islamic lectures at public community halls in Japan.
From the above findings, we can conclude that Indonesian culture has a strong gathering style, and this activity is maintained in the Japanese environment.

\section{References}

1) YAMAMOTO Seiki - NAKAOKA Toshisuke·GOTO Ryutaro • OTANI Satoshi: "Awig-Awig"in Timbrah Bali: A fundamental study of city formation from the axis4-, Summaries of Technical Papers of Annual Meeting Architectural Institute of Japan F-1, pp523-524, 1997.7.30

2) SAWADA Tomoko: Some considerations about daily and non-daily lives within public space in the dwelling units: A study of dwellings in terms of behavioral environment, focussing on recent trends of seating style and composition of behavioral places, in the Part 1, Journal of Architecture Planning and Environmental Engineering (511), pp83-90, 1998.09.30

3) LI Bin · FUNAHASHI Kunio - OKU Toshinobu - SUZUKI Takeshi • KOURA Hisako-KITA Michihiro: A Study on changing process of sitting styles in China, Journal of Architecture Planning and Environmental Engineering (518), pp145-151, 1999.04.30

4) DUDY Wiyancoko·MIYAZAKI Kiyoshi: Representational Function of Seating Facilities Design-Representational Characteristics and Semantics of Seating Facilities in Javanese Society of Indonesia-, Bulletin of Japanese Society for Science of Design 46(2), pp45-54, 1999.7.31

5) YAMAMOTO Aoi · SUZUKI Takeshi - MATSUBARA Shigeki · YOSHIZUMI Yuko · ABDUL Mufti Radja - KOSAKA Mariko • YAMAUCHI Kiyoshi- OKU Toshinobu: Gathering on the street furniture "Bale Bale" in Lae Lae Island in Indonesia, Summaries of Technical Papers Kinki Branch Architectural Institute of Japan(52), pp57-60, 2012.05.25

6) http://www.tbm110.org/2012/12/meriah-dan-khidmat-milad-tbm-110-f k-umi.html, 2012.08.08

\section{Notes}

i) Tudang Sipulung comes from the Bugis-Makassar language meaning sitting together and discussing an issue, then find the best solution.

ii) Barugas in a general sense is a place or building that is used as a gathering place. A long time ago barugas often used as a meeting place and deliberation. The shape of barugas is quite simple (just using floor and roof) and without walls. Because the shape of barugas is half-open (without walls), so the gathering which was held in barugas also be open (can be attended by anyone).

iii) Bale-bale is a type of seat that is frequently used by the community to gather and engage in a variety of activities. Bale-bale made by bamboo, wood, or combination of both. The bale-bale has ownership, but can be used for public.

iv) Tikar (mat) is a tool that is usually placed on the floor for a seat or bed, made of webbing or carpet material.

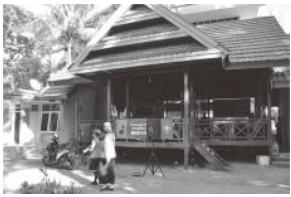

ii) Baruga

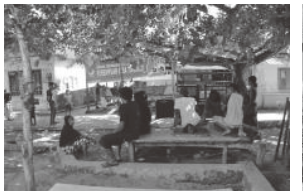

iii) Bale-bale

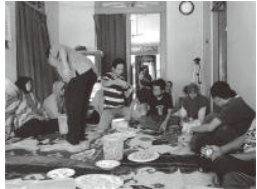

iv) Tikar v) Living room (ruang tamu) is a room that is usually found on the front of a house. Its function as a space where first-time guests to meet and to be hosted by the homeowner.

vi) Family room (ruang keluarga) is part of a house used as a gathering place for family members, and doing a variety of activities together. Most of houses in Indonesia had a family room. 


\section{和文要約}

本稿はインドネシアの人々の集まりの型・様式に関する調査研 究である。インドネシアには家族, 近隣, その他の集団で問題があ る時には, 皆で座って民主的に議論する Tudang Sipulung という慣 習がある。この時の集まりは規模に関わらず床座・車座で行われる のが原則である。インドネシアからの留学生とその家族に対するア ンケートとフィールド調查によって，1）インドネシア人は自宅に 人を招くことが一般的で, 現在住んでいる日本の住宅・団地でも 1 0 人以上を招く機会がしばしばあること, 故郷の住宅では何十人も のお客を招くのがごく普通であること。2 ) その時の集まりの型は, 日常は西洋式の家具を使っている場合でも, 床に敷物を敷いての車 座・床座が原則で, 男女のゾーンは分かれていること。3）公共施 設を使ってのイスラム教についての勉強会においても集まりはこの 様式であること。以上より, インドネシアには床座・車座で集まる 強い様式があり, それは日本の環境においても維持されていること が明らかになった。

(2014 年 9 月 9 日原稿受理, 2015 年 1 月 26 日採用決定) 